\title{
Thyroid Dysfunction in Iraqi Patients with Acromegaly
}

\author{
Selman Nihad $\mathbf{A}^{\mathbf{1}}$, Rahma Abbas $\mathbf{M}^{\mathbf{1}}$, Ali Atheer $\mathbf{Y}^{\mathbf{2}}$ \\ ${ }^{1}$ College of Medicine, University of Babylon; Babil; Iraq, ${ }^{2}$ Mustansiriayh University/ National Diabetes \\ Center/Iraq
}

\begin{abstract}
Acromegaly is a chronic endocrine disorder caused by hypersecretion of growth hormone (GH) mostly because of pituitary adenoma. GH induces the formation of Insulin like Growth Factor1 (IGF1)from the liver. Both GH andIGF1 lead to sign and symptom of acromegaly.

Aim: This study designed to identify the prevalence of thyroid dysfunction in Iraqi patients with acromegaly ,to identify the factors responsible for thyroid dysfunction in patients with acromegaly.Is the treatment modalities for acromegaly has a role in thyroid dysfunction?
\end{abstract}

Study design: A cross sectional case control study

Patients and Method: seventy patients with acromegaly were enrolled from 2 different tertiary centers of endocrinology from Jan. -Dec. 2017 compared with 70 non acromeglic subjects. Their mean age $46+/-11$ years ; forty one (58.5\%) males and 29(41.5\%)females. Thyroid function test conducted to both patients and control groups including TSH, free T4 and total T3 in both centers. In addition to other variables.

Results: Out of $70(100 \%)$ patients with acromegaly; (51.5\%) were euthyroid, (20\%) had primary hypothyroidism , (15.7\%)had central hypothyroidism and (12.8\%) had hyperthyroidism that is significantly higher than normal population $(\mathrm{p}<0.001)$.Patient with acromegaly had significant systolic and diastolic hypertension vs. control ( $\mathrm{p}=0.015,0.004$ respectively). Age of the patients, diastolic blood pressure, first $\mathrm{GH}$ and history of hypophysectomy were significant risk factors for thyroid dysfunction $(\mathrm{p}=0.02,0.008,0.008$ and 0.02 respectively)

Conclusion : Thyroid dysfunction is more prevalent in patient with acromegaly whether hypothyroidism (both primary and secondary) and hyperthyroidism. The Age and diastolic blood pressure are independent risk factors of thyroid dysfunction. There is significant role of hypophysectomy in thyroid dysfunction development while Sandostatin (Octreotide LAR) treatment had no role.

Key-words: thyroid dysfunction, acromegaly, hypothyroidism, central hypothyroidism, secondary hypothyroidism, hyperthyroidism.

\section{Introduction}

Acromegaly is a chronic endocrine disorder caused by hypersecretion of growth hormone $(\mathrm{GH})$ mostly because of pituitary adenoma (macroadenoma or less commonly microadenoma) .GH induces the formation of Insulin like Growth Factor1 (IGF1)from the liver [1]. GH and Insulin -like Growth Factor 1(IGF-1) act altogether to induce features of acral and visceral enlargement. Acromegaly is caused by tumors arising from anterior pituitary gland that secreting GH or very rarely by extrapituitary disorders ${ }^{[2]}$. GH secreted in a pulsatile fashion, while IGF1 levels are relatively stable with little diurnal variation ${ }^{[3]}$. It is evident through different studies that IGF1 play an important role in thyroidal cell growth. However it may be responsible for pathogenesis of different thyroid related diseases. One study shows that IGF-1 stimulated synthesis of protein and DNA as well as promoted thyroid cells proliferation and differentiation ${ }^{[4]}$.

The thyroid gland is an endocrine organ present at the front and sides of the neck, anterior to the trachea. The thyroid gland produces thyroid hormones that are 
responsible for regulation of metabolism as well as the development and differentiation of different body cells $^{[5]}$.

\section{Acromegaly and thyroid hormonal abnormalities:}

There are different factors responsible for thyroid stimulating hormone (TSH) secretion from anterior pituitary gland. The synthesis and secretion of TSH are under the inhibitory effect of T3 and T4 and stimulatory effect of TRH and to a lesser effect of other factors like ,leptin ,dopamine ,GH, IGF1 and somatostatin ${ }^{[6,7]}$. The thyroid gland sensitivity to TSH can be modulated by autonomous nervous system ${ }^{[8]}$.

TSH secretion has an important role for producing basic heat and energy homeostasis maintenance in the body ${ }^{[9]}$.

Studies show that TSH secretion from thyrotrophic cells can be modulated directly or indirectly by GH and IGF-1 ${ }^{[10]}$. In thyrotrophic cells; somatostatin inhibits TSH secretion through activation of two somatostatin receptor subtypes, SST2 and SST5 ${ }^{[11]}$. GH under physiological conditions exerts a negative feedback on somatostatin secretion from hypothalamus and this lead to reduce the growth -hormone releasing hormone (GHRH) secretion [12]. Thus, the increasing of somatostatin secretion has an impact on thyrotrophic cells that inhibit the TSH secretion. On the other hand, The GHRH has a synergistic effect on the TRH and further on TSH secretion both in healthy subjects and in patients with acromegaly ${ }^{[13]}$. As well as an increase in intrapituitary conversion of $\mathrm{T} 3$ to $\mathrm{T} 4$ in thyrotrophic cells because of GH excess can reduce TSH synthesis and secretion ${ }^{[14]}$. Moreover, because of the feedback mechanism, the GH excess with somatostatin participation has an inhibition effect on TSH secretion ${ }^{[6]}$. The TSH secretion can also be reduced by the presence of a pituitary tumor per se [10].

Also, acromegaly can cause panhypopituitarism because of compressing effect of the tumor mass on the surrounding tissue, therefore there may be secondary thyroid or adrenal failure hypogonadism or amenorrhea $^{[15,16]}$.

\section{Patients and method}

This is a cross sectional case control study in which seventy patients with acromegaly were enrolled in this study compared with 70 non-acromegalic subjects from
January 2017- December 2017 from 2 endocrinology specialized centers.

An informed consent have been obtained from all patients and control counterparts, signed and dated before participation in this study.

The enrolled subjects were already diagnosed as acromegaly clinically, biochemically and radiologically.

They fulfill the definition of being acromegalic as their IGF1 exceed the cutoff value for their age and sex ,GH level above the reference range and GH fail to drop below $1 \mathrm{ng} / \mathrm{ml}$ in response to glucose tolerance test. The diagnosis was fortified by detection of pituitary adenoma by MRI either microadenoma $(<10 \mathrm{~mm}$ in diameter) or macroadenoma $(>10 \mathrm{~mm}$ in diameter $)$.

When the GH drop to $<1 \mathrm{ng} / \mathrm{ml}$ and the IGF1 level became within the reference range that is age and sex matched on serial follow up period considered as [inactive]; while those who not met these criteria considered as [active]. The information were written in prepared printed forum including the name, age, sex, height, weight, systolic and diastolic blood pressure ,duration of acromegaly, size of tumor (micro or macroadenoma), history of hypophysectomy, radiotherapy or gamma knife ,medical therapy (type, dose of somatostatin analogue Long Acting Repeatable (LAR), number of injections) $\mathrm{GH}$ level in $1^{\text {st }}$ and last visits, IGF1 in $1^{\text {st }}$ and last visits, disease activity (according to last GH,IGF1 clinical assessment), history of smoking, and family history of thyroid disease.

Thyroid function tests were requested (TSH (reference range 0.4-4.2 mIU/L), free T4(reference rang of kit $0.7-1.9 \mathrm{ng} / \mathrm{dl}$ ) and total T3(80-180ng/dl)[measured by electrochemiluminescence immunoassay]. GH level (obtained from the registered data at first and last visit(by chemiluminescent immunoassay)) and IGF1level(according to sex and age matched limits) (also from the registered data at first and last visit (measured by immunochemiluminomertic assay (ICMA)))

Continuous variables were expressed by mean $+/-$ SD while categorical variables as percentage , all these collected data and variables analyzed by using crosstab chi square test for categorical variables or Student's paired t-test for continuous variable and ANOVA test between categorical and continuous variables. The value of $<0.05$ considered as statistically significant. 


\section{Results}

The subjects of this study were 70 patients with acromegaly with a mean age $46+/-11$ years .Forty one $(58.5 \%)$ males and 29(41.5\%)females disease duration from time of diagnosis differ with a range from 1year -30 years (average $8+/-6$ ). A growth hormone producing macroadenoma was the cause of acromegaly in 62 patients $(88.5 \%)$ and in the remaining $8(11.5 \%)$ had microadenoma . Thirty six (51.4\%) underwent neurosurgical treatment in form of hypophysectomy; 2 of them underwent hypophysectomy twice and another 2 underwent hypophysectomy thrice .Six patients (8.5\%) exposed to gamma knife and another one to conventional radiotherapy. All of our patients (even who had history of hypophysectomy or gamma knife after the intervention if they didn't achieve a remission immediately) received medical treatment in form of

monthly Octreotide (Sandostatin LAR) injection). Hypophysectomy, radiotherapy and/or medical therapy for acromegaly induced a significant reduction of mean GH and IGF-1 levels (27.83+/- 25.69 vs. $4.73+/-6.72$ $\mathrm{ng} / \mathrm{ml}, \mathrm{p}<0.001$ and $772.15+/-521.9$ vs. $404.2+/-278.6$ $\mathrm{ng} / \mathrm{ml}, \mathrm{p}<0.001$ respectively) that is shown in figure (1), but both GH and IGF-1 values normalized only in $12(17.2 \%)$ at time of collecting the data $(5$ of them had a remission after surgery and medical treatment, 2 patients had remission after both surgery and gamma knife, one had remission after gamma knife and medical treatment, and 4 patients had remission after medical treatment only) ; while the remainder $58(82.8 \%)$ had active disease (including those with partial response ; those who had elevated IGF1 with normal GH or those with elevated GH with normal IGF1).

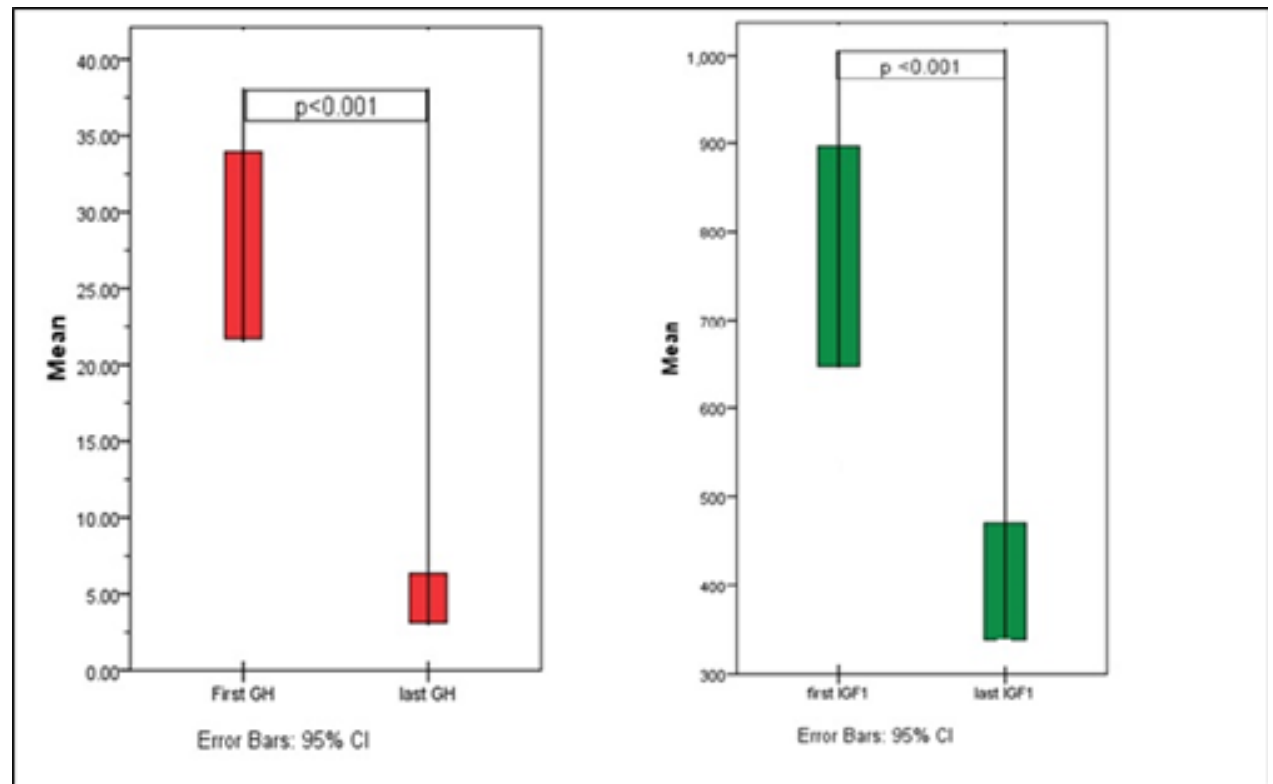

Figure (1) the comparison between the mean first and last result of both GH and IGF1.

The mean basal $\mathrm{GH}$ at time of diagnosis was $(27.83+/-25.7)$ and the mean last GH was $(4.73+/-6.72)$ with a percent of reduction were $(65.2 \%)$. While the mean basal IGF1 was $(772.15+/-522)$ and the mean last IGF1 was (404.26+/-278.62) with a percent of reduction were $(35.9 \%)$. Twenty eight $(40 \%)$ of patients were hypertensive, $13(18.5 \%)$ were smoker.
Family history revealed thyroid disease or goiter in $17(24.2 \%)$.

The control group was composed of 70 nonacromegalic subjects $(50 \%$ males) with a mean age of $43.54+/-7.17$ years. 
Table (1):The clinical and analytical comparison between patients with acromegaly and control groups.

\begin{tabular}{|c|c|c|c|c|}
\hline & & Acromegaly & Control & $P$ value \\
\hline \multicolumn{2}{|c|}{ Number(\%) } & $70(100)$ & $70(100)$ & \\
\hline \multicolumn{2}{|c|}{ Age mean +/- SD } & $46.21+/-10.9$ & $43.54+/-7.17$ & $0.07^{*}$ \\
\hline \multirow[t]{2}{*}{ Gender } & Male & $41(58.5)$ & $35(50)$ & \multirow[t]{2}{*}{$0.46+$} \\
\hline & Female & $29(41.5)$ & $35(50)$ & \\
\hline \multicolumn{2}{|c|}{$\begin{array}{l}\text { Body mass index mean }+/- \\
\text { SD }\end{array}$} & $29.03+/-4.92$ & $28.30+/-4.05$ & $0.38^{*}$ \\
\hline \multicolumn{2}{|c|}{ Systolic BP mean +/- SD } & $132.55+/-23.73$ & $123.64+/-18.19$ & $0.015 *$ \\
\hline \multicolumn{2}{|c|}{ Diastolic BP mean +/- SD } & $86.64+/-17.1$ & $79.07+/-14.2$ & $0.004 *$ \\
\hline \multicolumn{2}{|c|}{ Euthyroid } & $36(51.4)$ & $67(95.7)$ & \multirow[t]{4}{*}{$<0.001 \dagger$} \\
\hline \multicolumn{2}{|c|}{ hyperthyroid } & 9 (12.9) & $1(1.4)$ & \\
\hline \multicolumn{2}{|c|}{ primary hypothyroid } & $14(20.7)$ & $2(2.9)$ & \\
\hline \multicolumn{2}{|c|}{ central hypothyroid } & $11(15.7)$ & $0(0)$ & \\
\hline \multicolumn{2}{|c|}{ TSH mean +/- SD } & $12.7889+/-23.3$ & $2.1721+/-1.90$ & $<0.001^{*}$ \\
\hline \multicolumn{2}{|c|}{ free T4 mean +/- SD } & $1.149+/-0.75$ & $1.3737+/-0.34$ & $0.028 *$ \\
\hline \multicolumn{2}{|c|}{ total T3 mean +/- SD } & $114.3+/-67.2$ & $132.8571+/-22.67$ & $0.027^{*}$ \\
\hline
\end{tabular}

* Paired sample T-test

+ Cross tabulation Chi-square test 
Table (2):the general clinical characteristics of patients with acromegaly subdivided according to thyroid function:

\begin{tabular}{|c|c|c|c|c|c|c|c|}
\hline \multicolumn{2}{|l|}{ Variables } & Euthyroid & hyperthyroid & $\begin{array}{c}\text { primary } \\
\text { hypothyroid }\end{array}$ & $\begin{array}{c}\text { central } \\
\text { hypothyroid }\end{array}$ & total & $\begin{array}{c}P \\
\text { value }\end{array}$ \\
\hline \multicolumn{2}{|c|}{ Number (\%) } & $36(51.5)$ & $9(12.8)$ & $14(20)$ & $11(15.7)$ & $70(100)$ & \\
\hline \multicolumn{2}{|c|}{ Age mean $+/-S D$} & $46.9+/-11.3$ & $54.6+/-8.2$ & $41.2+/-10.3$ & $43.2+/-8.9$ & $46.2+/-11$ & $0.02 *$ \\
\hline \multirow{2}{*}{ Gender } & \begin{tabular}{|l|} 
Male \\
No.(\%) \\
\end{tabular} & $25(61)$ & $6(14.6)$ & $5(12.2)$ & $5(12.2)$ & $41(100)$ & \multirow[t]{2}{*}{$0.12^{\dagger}$} \\
\hline & $\begin{array}{l}\text { Female } \\
\text { No. }(\%)\end{array}$ & 11(37.9) & $3(10.3)$ & $9(31)$ & $6(20.6)$ & $29(100)$ & \\
\hline \multirow{2}{*}{$\begin{array}{l}\text { Family } \\
\text { history of } \\
\text { thyroid } \\
\text { disease }\end{array}$} & $\begin{array}{l}\text { Present } \\
\text { No.(\%) }\end{array}$ & $5(29.4)$ & $3(17.6)$ & $5(29.4)$ & $4(23.5)$ & $17(100)$ & \multirow[t]{2}{*}{$0.22 \dagger$} \\
\hline & $\begin{array}{l}\text { Absent } \\
\text { No.(\%) }\end{array}$ & $13(58.5 \%)$ & $6(11.3 \%)$ & $9(17 \%)$ & $7(13.2 \%)$ & $53(100 \%)$ & \\
\hline \multicolumn{2}{|c|}{ BMI (mean+/-SD) } & $28.3+/-4.4$ & $30.9+/-4.1$ & $27.9+/-5.3$ & $31.4+/-6$ & $29 .+/-5$ & $0.13 *$ \\
\hline \multirow{2}{*}{$\begin{array}{l}\text { Hypertens } \\
\text { ion }\end{array}$} & \begin{tabular}{|l} 
Hyperten \\
sive \\
No.(\%)
\end{tabular} & $12(42)$ & $5(18)$ & $7(25)$ & $4(14)$ & $28(100)$ & \multirow[b]{2}{*}{$0.5 \dagger$} \\
\hline & $\begin{array}{l}\text { Not } \\
\text { hyperten } \\
\text { sive } \\
\text { No.(\%) }\end{array}$ & $24(57)$ & $4(9.5)$ & $7(16.6)$ & $7(16.6)$ & $42(100)$ & \\
\hline \multicolumn{2}{|c|}{$\begin{array}{l}\text { Systolic Blood } \\
\text { Pressure (mean+/-SD) }\end{array}$} & $129.4+/-24$ & $140.5+/-24.3$ & $\begin{array}{c}136.42+/- \\
24.6\end{array}$ & $\begin{array}{c}131.36+/- \\
22.26\end{array}$ & $\begin{array}{c}132.55+/- \\
23.73\end{array}$ & $0.57^{*}$ \\
\hline \multicolumn{2}{|c|}{$\begin{array}{l}\text { Diastolic Blood } \\
\text { Pressure (mean+/-SD) }\end{array}$} & $\begin{array}{c}83.47+/- \\
16.42\end{array}$ & $81.67+/-15$ & $\begin{array}{c}100.35+/- \\
16.6\end{array}$ & $83.63+/-14$ & $\begin{array}{c}86.64+/- \\
17\end{array}$ & $\begin{array}{c}0.008 \\
*\end{array}$ \\
\hline \multirow{2}{*}{$\begin{array}{l}\text { Smoking } \\
\text { history }\end{array}$} & \begin{tabular}{|l|} 
Smokers \\
No.(\%)
\end{tabular} & $9(69.2)$ & $2(12.4)$ & $1(7.7)$ & $1(7.7)$ & $13(100)$ & \multirow{2}{*}{$0.4 \dagger$} \\
\hline & \begin{tabular}{|l|} 
Not \\
smoker \\
No.(\%)
\end{tabular} & $27(47.4)$ & $7(12.3)$ & $13(22.8)$ & $10(17.5)$ & $57(100)$ & \\
\hline \multicolumn{8}{|c|}{ * ANOVA test } \\
\hline \multicolumn{8}{|c|}{$\dagger$ Cross tabulation Chi-square test } \\
\hline
\end{tabular}


Table (3):The specific clinical characteristics of patients with acromegaly subdivided according to thyroid function:

\begin{tabular}{|c|c|c|c|c|c|c|c|}
\hline \multicolumn{2}{|l|}{ Variables } & Euthyroid & hyperthyroid & primary & central & total & $P$ value \\
\hline \multirow[t]{2}{*}{ Adenoma size } & No.(\%) & $4(50)$ & $2(25)$ & $1(12.5)$ & $1(12.5)$ & $8(100)$ & \multirow[t]{2}{*}{$0.7 *$} \\
\hline & $\begin{array}{l}\text { macroadenoma } \\
\text { No.(\%) }\end{array}$ & $32(51.6)$ & $7(11.3)$ & $13(20.9)$ & $10(16.2)$ & $62(100)$ & \\
\hline \multirow[t]{2}{*}{$\begin{array}{l}\text { Activity of } \\
\text { Acromegaly }\end{array}$} & $\begin{array}{l}\text { Active } \\
\text { No.(\%) }\end{array}$ & $28(48.2)$ & $8(13.8)$ & $14(24.1)$ & $8(13.8)$ & $58(100)$ & \multirow[t]{2}{*}{$0.2 *$} \\
\hline & $\begin{array}{l}\text { Inactive } \\
\text { No.(\%) }\end{array}$ & $8(66.7)$ & $1(8.30$ & $0(0)$ & $3(25)$ & $12(100)$ & \\
\hline \multicolumn{2}{|c|}{$\begin{array}{l}\text { Duration of acromegaly (Mean } \\
+ \text { +/-SD) }\end{array}$} & $7.5+/-6$ & $8.0+/-7.5$ & $7.1+/-7.3$ & $11.9+/-8.6$ & $8 .+/-7$ & $0.2+$ \\
\hline \multicolumn{2}{|c|}{ First GH (Mean +/-SD) } & $\begin{array}{l}25.07+/- \\
23.54\end{array}$ & $\begin{array}{l}21.36+/- \\
20.43\end{array}$ & $\begin{array}{c}20.65+/- \\
19.13\end{array}$ & $\begin{array}{c}51.26+/- \\
32.67\end{array}$ & $\begin{array}{c}27.83+/- \\
25.7\end{array}$ & $0.008+$ \\
\hline \multicolumn{2}{|c|}{ Last GH (Mean +/-SD) } & $\begin{array}{l}4.53+/- \\
7.02\end{array}$ & $3.40+/-3.87$ & $5.61+/-7.2$ & $5.34+/-7.54$ & $\begin{array}{c}4.73+/- \\
6.72\end{array}$ & $0.87+$ \\
\hline \multicolumn{2}{|c|}{ First IGF1 (Mean +/-SD) } & $\begin{array}{l}867.83+/- \\
565.88\end{array}$ & $\begin{array}{l}735.72+/- \\
493.6\end{array}$ & $\begin{array}{l}810.25+/- \\
529.16\end{array}$ & $\begin{array}{l}440.34+/- \\
207.7\end{array}$ & $\begin{array}{c}772.15+/- \\
522\end{array}$ & $0.12+$ \\
\hline \multicolumn{2}{|c|}{ Last IGF1 (Mean +/-SD) } & $\begin{array}{c}432.9+/- \\
285.51 \\
\end{array}$ & $\begin{array}{c}261.34+/- \\
145.82 \\
\end{array}$ & $\begin{array}{c}502.67+/- \\
319.65\end{array}$ & $\begin{array}{c}302.26+/- \\
232.74\end{array}$ & $\begin{array}{c}404.26+/- \\
278.62 \\
\end{array}$ & $0.11+$ \\
\hline \multicolumn{2}{|c|}{$\begin{array}{l}\text { Dose of Sandostatin (Mean +/- } \\
\text { SD) }\end{array}$} & $\begin{array}{l}742.77+/- \\
446\end{array}$ & $\begin{array}{l}677.77+/- \\
512\end{array}$ & $\begin{array}{l}549.28+/- \\
536\end{array}$ & $\begin{array}{l}736.36+/- \\
496\end{array}$ & $\begin{array}{c}694.71+/- \\
476.5\end{array}$ & $0.63+$ \\
\hline \multirow[t]{2}{*}{$\begin{array}{l}\text { History of } \\
\text { hypophysectom }\end{array}$} & \begin{tabular}{l|l} 
& $\begin{array}{l}\text { present } \\
\text { No.(\%) }\end{array}$ \\
\cline { 2 - 3 }
\end{tabular} & $13(36.1)$ & $4(11.1)$ & $10(27.8)$ & $9(25)$ & $36(100)$ & \multirow{2}{*}{$0.02^{*}$} \\
\hline & $\begin{array}{l}\text { absent } \\
\text { No.(\%) }\end{array}$ & $23(67.6)$ & $5(14.7)$ & $4(11.8)$ & $2(5.9)$ & $34(100)$ & \\
\hline \multirow[t]{2}{*}{$\begin{array}{l}\text { History of } \\
\text { Radiotherapy }\end{array}$} & $\begin{array}{l}\text { Present } \\
\text { No.(\%) }\end{array}$ & $4(57.1)$ & $1(14.3)$ & $2(28.6)$ & $0(0)$ & $7(100)$ & \multirow{2}{*}{$0.66^{*}$} \\
\hline & $\begin{array}{l}\text { Absent } \\
\text { No.(\%) }\end{array}$ & $32(50.8)$ & $8(12.7)$ & 12(19) & $11(17.5)$ & $63(100)$ & \\
\hline
\end{tabular}

Table 1 shows the clinical and analytical characteristics between patients with acromegaly and control groups. The systolic blood pressure was higher in patients with acromegaly compared to control subjects $(132.55+/-23.73$ vs. $123.64+/-18.19$ respectively $P$ $=0.015)$. The diastolic blood pressure was also higher in patients with acromegaly compared to control subjects $(86.64+/-17.1$ vs. $79.07+/-14.2$ respectively $\mathrm{P}=0.004)$ .There is significant thyroid dysfunction in patients with acromegaly compared to control subjects ( $p$ value $<0.001)$. As well as there is significant differences in mean TSH, free T4, total T3 of patients with acromegaly compared to control subjects (with $\mathrm{P}$ value $<0.001$, $0.028,0.027$ respectively)
In table 2 the acromegalic patients were subdivided into 4 main group according to their thyroid function into euthyroid $36(51.5 \%)$, hyperthyroidism $9(12.8 \%)$, primary hypothyroidism $14(20 \%)$ and central hypothyroidism 11(15.7\%).Then the analysis of variance in between subgroups conducted to identify the differences in variables of general clinical characteristics which shows that the age is significant risk factor $(\mathrm{p}=0.02)$ and the diastolic blood pressure also significantly different between subgroups $(\mathrm{p}=0.008)$.

In table 3 the analysis of variance conducted to the subgroups of patients with acromegaly that were already classify according to their thyroid status to identify the 
differences of specific acromegalic characteristics of variables which shows the significance of basal growth hormone level at time of diagnosis as well as the history of neurosurgical treatment (hypophysectomy) on the thyroid status ( $\mathrm{p}=0.008,0.02$ respectively). There is no significant correlations between thyroid status from one side and pituitary adenoma size, activity of disease ,duration of disease ,history of radiotherapy treatment, last GH and basal or last IGF1 on the other side.

\section{Discussion}

Most of our patients with acromegaly were in euthyroid status (51\%) while there is $20 \%$ had primary hypothyroidism, in addition to $15.7 \%$ had central (secondary) hypothyroidism and only $12.8 \%$ had hyperthyroidism; these findings are accepted if it is compared with Cannavo S. et al study that show the approximate levels of euthyroidism of about (67\%) and about $25 \%$ have hypothyroidism ${ }^{[17]}$. As well as we can accept our result regarding hyperthyroidism if we compared it with other study that found in 3.5$26 \%$ of patients with acromegaly in previous studies ${ }^{[18]}$. Thyrotoxicosis is not frequent [18], but it increases cardiovascular risk, particularly when is coupled with high GH and IGF-1 levels, and for that reason it is important to gain euthyroidism as fast as possible. Hyperthyroidism should be taken into consideration in diagnosing a patient with acromegaly and weight loss, after excluding cancer ${ }^{[19]}$.

Lastly we fail to found relationships between thyroid dysfunction from one side and duration of disease, last $\mathrm{GH}$, first or last IGF1 on the other side which are similar to what is found in other studies like Cannavo et al ${ }^{[17]}$.

\section{Conclusion}

Thyroid dysfunction is more prevalent in patient with acromegaly whether hypothyroidism (both primary and secondary) and hyperthyroidism. The Age and diastolic blood pressure are significant risk factors of thyroid dysfunction. There is significant role of hypophysectomy in thyroid dysfunction development while Sandostatin (Octreotide LAR) treatment had no role.

Ethical Clearance: The Research Ethical Committee at scientific research by ethical approval of both environmental and health and higher education and scientific research ministries in Iraq
Conflict of Interest: The authors declare that they have no conflict of interest.

Funding: Self-funding

\section{References}

1. Melmed S. Acromegaly. $N$ Engl J Med. 1990;322:966-77.

2. Melmed S. Medical progress: acromegaly. N Engl J Med. 2006;355: 2558-2573.

3. Jorgensen JO, Blum WF, Moller N, Ranke MB and Christiansen JS: Circadian patterns of serum insulinlike growth factor (IGF) II and IGF binding protein 3 in growth hormone-deficient patients and ageand sex-matched normal subjects. Acta Endocrinol (Copenh) 123: 257-262, 1990.

4. Kimura T, van Keymeulen A, Golstein J, Fusco A, Dumont JE and Roger PP: Regulation of thyroid cell proliferation by TSH and other factors: a critical evaluation of in vitro models. Endocr Rev 22: 631656, 2001.

5. Carlson GW: Surgical anatomy of the neck. Surg Clin North Am 73: 837-852, 1993.

6. Mariotti S. Normal physiology of the hypothalamic pituitary-thyroidal system and relation to the neural system and other endocrine gland. 2006; Chap 4. Thyroid disease manager. www.thyroidmanager.org

7. Hollenberg AN. The role the thyrotropin-releasing hor mone (TRH) neuronas metabolic sensor. Thyroid 2008; 18: 131-9. 35. Lechan RM, Fekete C. The TRH neuron: a hypothalamic integrator ofenergy metabolism. Prog Brain Res 2006; 153: 209-35.

8. Kalsbeek A, Fliers E, Franke AN, Wortel J, Buijs RM. Functional connections between the suprachiasmatic nucleus and the thyroid gland as revealed by lesioning and viral tracing techniques in the rat. Endocrinology 2000; 141: 3832-41.

9. Morley JE. Neuroendocrine control of thyrotropin secretion. Endocr Rev 1981; 2: 396-436.

10. Roelfsema F, Biermasz NR, Frolich M, Keenan DM, Veldhuis JD, Romijn JA. Diminished and irregular thyro tropin secretion with preserved diurnal rhytm in patients with active acromegaly. $\mathrm{J}$ Clin Endocrinol Metab 2009; 94: 1945-50.

11. Hofland LJ, Lamberts SW. Somatostatin receptor in pituitary function, diagnosis and therapy. Front Horm Res 2004; 32: 235-52. 
12. Giustina A, Veldhuis JD. Pathophysiology of the neuro regulation of growth hormone secretion in experimental animals and the human. Endocr Rev 1998; 19: 717-97.

13. Looij BJ, Roelfsema F, Frölich M, Nieuwenhuijzen Kruseman AC. The interaction of GHRH with TRH in acromegaly: a controlled study. Acta Endocrinol (Copenh) 1991; 125: 337-41.

14. Geelhoed-Duijvestijn PH, Roelfsema F, Schrödervan der Elst JP, van Doorn J, van der Heide. Effect of administration of growth hormone on plasma and intracellular levels of thyroxine and tri-iodothyronine in thyroidectomized thyroxinetreated rats. J Endocrinol 1992; 133: 45-9.

15. Drange MR, Fram NR, Herman-Bonert V, Melmed S. Pituitary tumor registry: a novel clinical resource. J ClinEndocrinolMetab. 2000;85168-174.

16. Katznelson L, Kleinberg D, Vance ML, et al. Hypogonadism in patientswith acromegaly: data from the multi-centre acromegaly registry pilot study. Clin Endocrinol (Oxf). 2001;54:183-188.

17. Cannavo S, Squadrito S, Finocchiaro MD, et al. Goiter and impairment of thyroid function in acromegalic patients: basal evaluation and followup. Horm Metab Res 2000; 32: 190-5.

18. Marzullo P, Cuocolo A, Ferone D, et al. Cardiac effect of thyrotoxicosis in acromegaly. J Clin Endocrinol Metab 2000; 85: 1426-32.

19. Burgos Peláez R, Simó Canonge R, HernándezPascual C, Mesa Manteca J. Acromegaly and Graves-Basedow disease. Report of 3 cases. Med Clin (Barc) 1994; 103: 179-80.

20. Figure (1) the comparison between the mean first and last result of both GH and IGF1.

21. Table (1):The clinical and analytical comparison between patients with acromegaly and control groups.

22. Table (2):the general clinical characteristics of patients with acromegaly subdivided according to thyroid function:

23. Table (3): The specific clinical characteristics of patients with acromegaly subdivided according to thyroid function: 